\title{
Massilia niabensis sp. nov. and Massilia niastensis sp. nov., isolated from air samples
}

Correspondence

Soon-Wo Kwon

swkwon@rda.go.kr

\author{
Hang-Yeon Weon, ${ }^{1}$ Byung-Yong $\mathrm{Kim}^{2}{ }^{2}$ Seung-Beom Hong, ${ }^{2}$ \\ Young-Ah Jeon, ${ }^{2}$ Bon-Sung Koo, ${ }^{2}$ Soon-Wo Kwon ${ }^{2}$ \\ and Erko Stackebrandt ${ }^{3}$
}

\begin{abstract}
${ }^{1}$ Applied Microbiology Division, National Institute of Agricultural Science and Technology, Rural Development Administration (RDA), Suwon 441-707, Republic of Korea

${ }^{2}$ Korean Agricultural Culture Collection (KACC), National Institute of Agricultural Biotechnology, RDA, Suwon 441-707, Republic of Korea

${ }^{3}$ DSMZ - Deutsche Sammlung von Mikroorganismen und Zellkulturen GmbH, Inhoffenstraße 7b, D-38124 Braunschweig, Germany
\end{abstract}

\begin{abstract}
Two bacterial isolates, designated strains $5420 \mathrm{~S}-26^{\top}$ and $5516 \mathrm{~S}-1^{\top}$, were recovered from air samples collected in Suwon, Korea. Cells of both strains were aerobic, Gram-negative, motile rods. Phylogenetically, these strains were positioned within the radius of the genus Massilia. 16S rRNA gene sequence analysis showed that the strains shared $97.3 \%$ sequence similarity and had sequence similarities of 94.9-98.1\% with respect to type strains of species belonging to the genus Massilia. In DNA-DNA hybridization tests, the two strains showed $<39 \%$ relatedness with respect to strains of closely related species of the genus Massilia and $27 \%$ relatedness to each other. Both strains contained $\mathrm{Q}-8$ as the predominant isoprenoid quinone and possessed summed feature 3 (comprising $\mathrm{C}_{16: 1} \omega 7 \mathrm{c}$ and/or iso- $\mathrm{C}_{15: 0} 2-\mathrm{OH}$ ) as the major fatty acid. Strain $5516 \mathrm{~S}-1^{\top}$ was found to contain the fatty acid $\mathrm{C}_{20: 0}$ (in small amounts), a feature that served to distinguish it from both $5420 S-26^{\top}$ and recognized members of the genus Massilia. The DNA $\mathrm{G}+\mathrm{C}$ contents of $5420 \mathrm{~S}-26^{\top}$ and $5516 \mathrm{~S}-1^{\top}$ were 67.8 and $66.6 \mathrm{~mol} \%$, respectively.

Phylogenetic, phenotypic and chemotaxonomic data accumulated in this study revealed that 5420S- $26^{\top}$ and $5516 \mathrm{~S}-1^{\top}$ represent novel species of the genus Massilia, for which the names Massilia niabensis sp. nov. (type strain $5420 \mathrm{~S}-26^{\top}=$ KACC $12632^{\top}=\mathrm{DSM} 21312^{\top}$ ) and Massilia niastensis sp. nov. (type strain $5516 \mathrm{~S}-1^{\top}=$ KACC $12599^{\top}=\mathrm{DSM} 21313^{\top}$ ) are proposed, respectively.
\end{abstract}

The genus Massilia was first proposed by La Scola et al. (1998) for an isolate from the blood of an immunocompromised patient with cerebellar lesions. Since then, other Massilia strains have been isolated from air, soil and water (Gallego et al., 2006; Zhang et al., 2006; Weon et al., 2008; $\mathrm{Zul}$ et al., 2008). The genus comprises aerobic, Gramnegative, motile, non-spore-forming rods or short rods. Summed feature 3 (comprising $\mathrm{C}_{16: 1} \omega 7 c$ and/or iso- $\mathrm{C}_{15: 0}$ 2-OH) and $\mathrm{C}_{16: 0}$ are the major fatty acids, Q-8 is the predominant isoprenoid quinone and the DNA $\mathrm{G}+\mathrm{C}$ content is relatively high $(63.3-68.9 \mathrm{~mol} \%)$.

Air samples were collected in the Suwon region of Korea $\left(37^{\circ} 16^{\prime} 46^{\prime \prime} \mathrm{N} 126^{\circ} 59^{\prime} 10^{\prime \prime} \mathrm{E}\right)$ by using an MAS-100 air sampler (single-stage multiple-hole impactor; Merck) that contained Petri dishes with R2A medium (Reasoner \&

The GenBank/EMBL/DDBJ accession numbers for the 16S rRNA gene sequences of strains $5516 \mathrm{~S}-1^{\top}$ and $5420 S-26^{\top}$ are EU808005 and EU808006.
Geldreich, 1985) supplemented with cycloheximide (Sigma) at $200 \mu \mathrm{g} \mathrm{ml}^{-1}$. After incubation at $28{ }^{\circ} \mathrm{C}$ for 5 days, two bacterial strains, designated $5420 \mathrm{~S}-26^{\mathrm{T}}$ and $5516 \mathrm{~S}-1$, were isolated that were shown to be phylogenetically related to members of the genus Massilia.

After $24 \mathrm{~h}$ incubation at $28{ }^{\circ} \mathrm{C}$, the cell morphologies of these novel strains were examined by means of light microscopy (Axio; Zeiss) and transmission electron microscopy (model 912AB; LEO). Phenotypic characteristics such as Gram staining, catalase activity, oxidase activity and hydrolysis of CM-cellulose, casein, chitin, DNA, hypoxanthine, pectin, tyrosine, Tween 80 , starch and xanthine were performed using the methods of Smibert \& Krieg (1994). The $\mathrm{pH}$ range for growth was determined in R2A broth adjusted to $\mathrm{pH} 4.0-10.0$, in increments of 1.0 $\mathrm{pH}$ unit, with citrate/phosphate or Tris/HCl (Breznak \& Costilow, 1994). Growth at 0, 1, 2, 3 and $5 \% \mathrm{NaCl}(\mathrm{w} / \mathrm{v})$ was investigated in $\mathrm{R} 2 \mathrm{~A}$ broth. Growth at various 
temperatures $\left(5-45{ }^{\circ} \mathrm{C}\right)$ was measured on $\mathrm{R} 2 \mathrm{~A}$ agar. Growth under anaerobic conditions was tested in GasPak (BBL) jars at $28{ }^{\circ} \mathrm{C}$ for 15 days. Physiological and biochemical properties were further determined with API 20NE, API ID 32GN and API ZYM strips (all from bioMérieux). Tests involving commercial systems were generally performed according to the manufacturer's instructions. The API ZYM test strip was read after $4 \mathrm{~h}$ incubation at $37{ }^{\circ} \mathrm{C}$ and the other API test strips were examined after 5 days at $28^{\circ} \mathrm{C}$.

The presence of isoprenoid quinones was investigated using HPLC, as described previously (Groth et al., 1996). Fatty acid methyl esters were extracted and prepared using the standard protocol of the Microbial Identification System (MIDI; Microbial ID) with cells that had been grown on R2A for $48 \mathrm{~h}$ at $28{ }^{\circ} \mathrm{C}$. DNA G $+\mathrm{C}$ contents were determined as described by Mesbah et al. (1989), using a reversed-phase column (Supelcosil LC-18 S; Supelco).

Colonies were used for PCR amplification of the 16S rRNA genes, using primers fD1 and rP2 (Weisburg et al., 1991); entire PCR fragments were sequenced directly (Hiraishi, 1992). The software package MEGA 3.1 (Kumar et al., 2004) was used for all analyses. Phylogenetic dendrograms were constructed using the neighbour-joining (Saitou \& Nei, 1987) and maximum-parsimony (Fitch, 1971) methods with bootstrap values based on 1000 replications. DNADNA hybridization was carried out using the filter hybridization method described by Seldin \& Dubnau (1985). Probe labelling was conducted by using the nonradioactive DIG-High Prime system (Roche) and hybridized DNA was visualized using the DIG luminescent detection kit (Roche). DNA-DNA relatedness was quantified by using a densitometer (Bio-Rad).

Both strains were aerobic, mesophilic, catalase- and oxidase-positive bacteria comprising rod-shaped cells. They grew well on R2A and nutrient agar (Difco) but did not grow on trypticase soy agar (Difco) or MacConkey agar (Difco). Differential phenotypic characteristics of the isolates and recognized members of the genus Massilia are shown in Table 1.

Both strains contained ubiquinone Q-8 as the predominant isoprenoid quinone. In terms of fatty acid composition, strain $5420 \mathrm{~S}-26^{\mathrm{T}}$ contained summed feature 3 (comprising $\mathrm{C}_{16: 1} \omega 7 c$ and/or iso- $\left.\mathrm{C}_{15: 0} 2-\mathrm{OH} ; 46.0 \%\right), \mathrm{C}_{16: 0}(23.6 \%)$, $\mathrm{C}_{12: 0}(8.9 \%), \mathrm{C}_{18: 1} \omega 7 c(7.8 \%)$ and $\mathrm{C}_{10: 0} 3-\mathrm{OH}(6.6 \%)$, while strain $5516 \mathrm{~S}-1^{\mathrm{T}}$ contained summed feature 3 (38.1\%), $\mathrm{C}_{16: 0}$ (26.9\%), $\mathrm{C}_{18: 1} \omega 7 c(12.3 \%), \mathrm{C}_{10: 0} 3-\mathrm{OH}$ $(5.5 \%), \mathrm{C}_{12: 0}(4.7 \%), \mathrm{C}_{20: 0}(2.6 \%)$ and $\mathrm{C}_{12: 0} 2-\mathrm{OH}$ $(2.4 \%)$. Comparisons of the fatty acid compositions of the novel isolates and recognized members of the genus Massilia are shown in Table 2.

For the phylogenetic analysis, 1398 and 1394 bp stretches, respectively, of the $16 \mathrm{~S}$ rRNA gene sequences for strains $5420 \mathrm{~S}-26^{\mathrm{T}}$ and $5516 \mathrm{~S}-1^{\mathrm{T}}$ were used. The sequence similarity between $5420 \mathrm{~S}-26^{\mathrm{T}}$ and $5516 \mathrm{~S}-1^{\mathrm{T}}$ was $97.3 \%$. Strain
5420S-26 $6^{\mathrm{T}}$ showed 95.3-98.1\% sequence similarity with respect to the type strains of the genus Massilia, having the highest level of similarity with the sequence of Massilia brevitalea byr $23-80^{\mathrm{T}}(98.1 \%)$. Strain $5516 \mathrm{~S}-1^{\mathrm{T}}$ shared sequence similarities in the range 94.9-98.1\% with respect to the type strains of the other species of the genus Massilia, the highest level of similarity being found with the sequence of Massilia aerilata KACC $12505^{\mathrm{T}}$ (98.1\%). Both strains showed relatively low sequence similarities $(<96 \%)$ with respect to members of other genera. The neighbourjoining phylogenetic tree (Fig. 1) clearly showed both strains to be members of the genus Massilia, revealing that strains $5420 \mathrm{~S}-26^{\mathrm{T}}$ and $5516 \mathrm{~S}-1$ clustered with Massilia aurea $\mathrm{AP} 13^{\mathrm{T}}$, M. brevitalea byr $23-80^{\mathrm{T}}$ and $M$. aerilata KACC $12505^{\mathrm{T}}$; the maximum-parsimony tree supported the phylogeny obtained with neighbour joining. In DNADNA hybridization tests, the relatedness between 5420S$26^{\mathrm{T}}$ and M. brevitalea DSM $18925^{\mathrm{T}}$, M. aurea DSM $18055^{\mathrm{T}}$ and strain $5516 \mathrm{~S}-1^{\mathrm{T}}$ was 39,30 and $26 \%$, respectively. For $5516 \mathrm{~S}-1^{\mathrm{T}}$, the values obtained with respect to $M$. aerilata KACC $12505^{\mathrm{T}}$ and strain $5420 \mathrm{~S}-26^{\mathrm{T}}$ were 37 and $28 \%$, respectively.

The phylogenetic and DNA-DNA hybridization data showed that the novel isolates were members of the genus Massilia, but that they represented two genomic species separable from recognized Massilia species. Phenotypically, strain $5420 \mathrm{~S}-26^{\mathrm{T}}$ can be differentiated from $5516 \mathrm{~S}-1^{\mathrm{T}}$ on the basis of the former's ability to reduce nitrate, its inability to hydrolyse aesculin or gelatin and its inability to assimilate various substrates. In addition, strain $5420 \mathrm{~S}-26^{\mathrm{T}}$ differs from M. brevitalea DSM $18925^{\mathrm{T}}$ in having oxidase, $\beta$-galactosidase and $\beta$-glucuronidase activities, lacking the ability to hydrolyse aesculin and casein and being unable to assimilate various substrates. Strain $5516 \mathrm{~S}-1^{\mathrm{T}}$ showed $\beta$ galactosidase activity, weak hydrolysis of starch, assimilation of $\mathrm{N}$-acetylglucosamine and maltose and the absence of nitrate reduction, urease activity, casein hydrolysis, esterase lipase (C8) activity and $\alpha$-glucosidase, unlike its closest relative, M. aerilata KACC $12505^{\mathrm{T}}$.

Therefore, on the basis of the phenotypic and genotypic data presented, strains $5420 \mathrm{~S}-26^{\mathrm{T}}$ and $5516 \mathrm{~S}-1^{\mathrm{T}}$ represent two novel species of the genus Massilia, for which the names Massilia niabensis sp. nov. and Massilia niastensis sp. nov., respectively, are proposed.

\section{Description of Massilia niabensis sp. nov.}

Massilia niabensis (ni.a.ben'sis. N.L. fem. adj. niabensis pertaining to NIAB, the National Institute of Agricultural Biotechnology, where taxonomic studies of the type strain were conducted).

Cells are aerobic, Gram-negative rods $(0.6-0.9 \times 1.4-$ $4.0 \mu \mathrm{m})$ that are motile by means of single polar flagella. Colonies are yellowish white, round and convex with clear margins. Grows well on R2A and nutrient agar, but does not grow on trypticase soy agar or MacConkey agar. Catalase- and oxidase-positive. Grows at 5-35 ${ }^{\circ} \mathrm{C}$ (optim- 
Table 1. Differential properties of strains $5420 \mathrm{~S}-26^{\top}$ and $5516 \mathrm{~S}-1^{\top}$ and type strains of recognized members of the genus Massilia

Strains: 1 , 5420S-26 ${ }^{\mathrm{T}} ; 2$, 5516S- $1^{\mathrm{T}} ; 3$, M. aerilata KACC $12505^{\mathrm{T}} ; 4$, M. albidiflava DSM $17472^{\mathrm{T}} ; 5$, M. aurea DSM $18055^{\mathrm{T}}$; 6, M. brevitalea DSM $18925^{\mathrm{T}} ; 7$, M. dura DSM $17513^{\mathrm{T}} ; 8$, M. lutea DSM $17473^{\mathrm{T}} ; 9$, M. plicata DSM $17505^{\mathrm{T}}$; 10, M. timonae DSM $16850^{\mathrm{T}}$. Data for reference strains were taken from Zul et al. (2008) (M. brevitalea DSM 18925 ) and Weon et al. (2008) (remaining strains) unless otherwise indicated. In API 20NE test strips, all of the strains are negative for indole production, glucose fermentation and arginine dihydrolase. In API ZYM test strips, all of the strains are positive for alkaline phosphatase, esterase (C4), leucine arylamidase, valine arylamidase, acid phosphatase and naphthol-AS-BIphosphohydrolase, but negative for lipase (C14), trypsin, $\alpha$-chymotrypsin, $N$-acetyl- $\beta$-glucosaminidase, $\alpha$-mannosidase and $\alpha$-fucosidase. + , Positive; (+), weakly positive; - , negative.

\begin{tabular}{|c|c|c|c|c|c|c|c|c|c|c|}
\hline Characteristic & 1 & 2 & 3 & 4 & 5 & 6 & 7 & 8 & 9 & 10 \\
\hline Catalase/oxidase & $+/+$ & $+1+$ & $+1+$ & $+1+{ }^{a \star}$ & $+/(+)^{b}$ & $(+) /-$ & $+1+^{a}$ & $+1+{ }^{a}$ & $+1-^{a}$ & $+1+^{c}$ \\
\hline Nitrate reduction & + & - & + & + & - & + & - & - & - & - \\
\hline Urease & - & - & + & - & - & $-{ }^{d}$ & - & - & - & - \\
\hline$\beta$-Galactosidase & + & + & - & + & + & $-{ }^{d}$ & + & + & - & + \\
\hline \multicolumn{11}{|l|}{ Hydrolysis of: } \\
\hline Aesculin & - & + & + & + & + & $+^{d}$ & + & + & + & + \\
\hline Casein & - & - & + & $+{ }^{e}$ & $+{ }^{e}$ & + & $+{ }^{e}$ & $+{ }^{e}$ & $+{ }^{e}$ & ND \\
\hline Gelatin & - & + & + & + & + & - & + & + & + & + \\
\hline Starch & + & $(+)$ & - & $+{ }^{e}$ & $+{ }^{e}$ & + & $-{ }^{e}$ & $+{ }^{e}$ & $+{ }^{e}$ & $+{ }^{e}$ \\
\hline \multicolumn{11}{|l|}{ Assimilation of: } \\
\hline D-Glucose & - & + & + & + & + & $+{ }^{d}$ & + & - & + & + \\
\hline L-Arabinose & - & + & + & + & - & $-{ }^{d}$ & + & + & + & + \\
\hline D-Mannose & - & + & + & + & + & $-{ }^{d}$ & + & + & + & + \\
\hline D-Mannitol & - & - & - & - & - & $-{ }^{d}$ & - & - & - & - \\
\hline$N$-Acetylglucosamine & - & + & - & + & + & $-{ }^{d}$ & - & + & - & - \\
\hline Maltose & - & + & + & + & + & $+^{d}$ & + & + & + & + \\
\hline Potassium gluconate & - & + & - & + & - & $-{ }^{d}$ & + & + & + & + \\
\hline Capric acid & - & - & - & - & - & $-{ }^{d}$ & - & - & - & - \\
\hline Adipic acid & - & - & - & + & + & $+^{d}$ & - & + & - & - \\
\hline Malic acid & - & + & + & - & + & $+^{d}$ & + & - & + & + \\
\hline Trisodium citrate & - & - & - & - & + & $-{ }^{d}$ & - & - & - & + \\
\hline Phenylacetic acid & - & - & + & - & - & $-{ }^{d}$ & - & - & - & + \\
\hline \multicolumn{11}{|l|}{ Enzyme activities } \\
\hline Esterase lipase (C8) & + & - & + & + & + & $+^{d}$ & + & + & + & + \\
\hline Cystine arylamidase & - & + & + & - & - & $-{ }^{d}$ & - & - & - & + \\
\hline$\alpha$-Galactosidase & - & - & - & + & - & $-{ }^{d}$ & + & - & + & - \\
\hline$\beta$-Glucuronidase & + & - & - & - & - & $-{ }^{d}$ & - & - & - & - \\
\hline$\alpha$-Glucosidase & + & - & + & - & $(+)$ & $+^{d}$ & - & - & - & - \\
\hline$\beta$-Glucosidase & - & - & - & + & - & $-{ }^{d}$ & - & - & - & $(+)$ \\
\hline DNA G $+\mathrm{C}$ content $(\mathrm{mol} \%)$ & 67.8 & 66.6 & 68.9 & $65.3^{a}$ & $66.0^{b}$ & 65.3 & $65.9^{a}$ & $63.3^{a}$ & $65.1^{a}$ & $64.6^{f}$ \\
\hline
\end{tabular}

${ }^{\star}$ Data taken from: $a$, Zhang et al. (2006); b, Gallego et al. (2006); c, Lindquist et al. (2003); $d$, this study; e, Zul et al. (2008); $f$, La Scola et al. (1998).

ally at $28{ }^{\circ} \mathrm{C}$ ) on $\mathrm{R} 2 \mathrm{~A}$, at $\mathrm{pH} 7-9$ (optimally at $\mathrm{pH} 7$ ) and $0-1 \% \mathrm{NaCl}$. Positive for nitrate reduction and $\beta$ galactosidase, but negative for indole production, glucose fermentation, arginine dihydrolase, urease, aesculin hydrolysis and gelatin hydrolysis (API 20NE test strips). Degrades hypoxanthine, starch, tyrosine and Tween 80, but does not degrade casein, chitin, CM-cellulose, DNA, pectin or xanthine. Does not assimilate any of the substrates embedded in the API 20NE and API ID 32GN test strips. Positive for alkaline phosphatase, esterase (C4), esterase lipase (C8), leucine arylamidase, valine arylamidase, acid phosphatase, naphthol-AS-BI-phosphohydrolase, $\beta$-glucuronidase and $\alpha$-glucosidase, but negative for lipase (C14), cystine arylamidase, trypsin, $\alpha$-chymotrypsin, $\alpha$-galactosidase, $\beta$-glucosidase, $N$-acetyl- $\beta$-glucosaminidase, $\alpha$-mannosidase and $\alpha$-fucosidase (API ZYM test strips). The major fatty acids $(>10 \%)$ are summed feature $3\left(\mathrm{C}_{16: 1} \omega 7 c\right.$ and/or iso- $\left.\mathrm{C}_{15: 0} 2-\mathrm{OH}\right)$ and $\mathrm{C}_{16: 0}$. The predominant ubiquinone is $\mathrm{Q}-8$. The DNA $\mathrm{G}+\mathrm{C}$ content of the type strain is $67.8 \mathrm{~mol} \%$.

The type strain, 5420S-26 $6^{\mathrm{T}} \quad$ =KACC $12632^{\mathrm{T}}=\mathrm{DSM}$ $21312^{\mathrm{T}}$ ), was isolated from an air sample collected from Suwon, Republic of Korea.

\section{Description of Massilia niastensis sp. nov.}

Massilia niastensis (ni.as.ten'sis. N.L. fem. adj. niastensis pertaining to NIAST, the National Institute of Agricultural 
Table 2. Cellular fatty acid compositions (\%) of strains $5420 \mathrm{~S}-26^{\top}$ and $5516 \mathrm{~S}-1^{\top}$ and type strains of recognized members of the genus Massilia

Strains: $1,5420 \mathrm{~S}-26^{\mathrm{T}} ; 2,5516 \mathrm{~S}-1^{\mathrm{T}} ; 3$, M. aerilata KACC $12505^{\mathrm{T}} ; 4$, M. albidiflava DSM $17472^{\mathrm{T}} ; 5$, M. aurea DSM $18055^{\mathrm{T}}$; 6, M. brevitalea DSM $^{2}$ $18925^{\mathrm{T}}$; 7, M. dura DSM $17513^{\mathrm{T}}$; 8, M. lutea DSM $17473^{\mathrm{T}}$; 9, M. plicata DSM $17505^{\mathrm{T}}$; 10, M. timonae DSM $16850^{\mathrm{T}}$. All data except those for M. plicata DSM $17505^{\mathrm{T}}$ (data from Zhang et al., 2006) were obtained in this study. All strains except M. albidiflava DSM $17472^{\mathrm{T}}$ and M. brevitalea DSM $18925^{\mathrm{T}}$ were grown at $28{ }^{\circ} \mathrm{C}$ on R2A for 2 days; cells of M. albidiflava DSM $17472^{\mathrm{T}}$ were harvested after growth at $28{ }^{\circ} \mathrm{C}$ on trypticase soy agar for 2 days, while cells of $M$. brevitalea DSM $18925^{\mathrm{T}}$ were harvested after growth at $15{ }^{\circ} \mathrm{C}$ for 2 days on R2A. - , Not detected or $<1 \%$.

\begin{tabular}{|lcccccccccc|}
\hline Fatty acid & $\mathbf{1}$ & $\mathbf{2}$ & $\mathbf{3}$ & $\mathbf{4}$ & $\mathbf{5}$ & $\mathbf{6}$ & $\mathbf{7}$ & $\mathbf{8}$ & $\mathbf{9}$ & $\mathbf{1 0}$ \\
\hline $\mathrm{C}_{10: 0} 3-\mathrm{OH}$ & 6.6 & 5.5 & 4.7 & 7.0 & 6.0 & 4.9 & 5.5 & 5.7 & 10.1 & 4.6 \\
$\mathrm{C}_{12: 0}$ & 8.9 & 4.7 & 3.4 & 5.3 & 4.4 & 5.0 & 3.9 & 4.0 & 7.1 & 3.3 \\
$\mathrm{C}_{12: 0} 2-\mathrm{OH}$ & - & 2.4 & - & - & - & 2.0 & - & - & 1.6 & 2.2 \\
$\mathrm{C}_{14: 0}$ & - & - & 1.9 & 2.6 & 2.0 & - & 1.1 & 1.2 & - & - \\
$\mathrm{C}_{14: 0} 2-\mathrm{OH}$ & - & - & 2.5 & 2.4 & 2.5 & - & 2.6 & 2.9 & 6.1 & - \\
$\mathrm{C}_{16: 0}$ & 23.6 & 26.9 & 30.6 & 23.4 & 27.2 & 23.0 & 27.5 & 26.6 & 25.1 & 30.5 \\
$\mathrm{C}_{17: 0}$ cyclo & - & 3.4 & 6.1 & - & - & - & - & - & - & 3.7 \\
$\mathrm{C}_{18: 1} \omega 7 c$ & 7.8 & 12.3 & 11.7 & 7.4 & 7.92 & 9.0 & 7.03 & 7.8 & 11.7 & 7.9 \\
$\mathrm{C}_{20: 0}$ & - & 2.6 & - & - & - & - & - & - & - & - \\
Summed feature $3^{*}$ & 46.0 & 38.1 & 35.2 & 46.0 & 48.6 & 54.2 & 52.0 & 51.1 & 36.9 & 47.0 \\
\hline
\end{tabular}

${ }^{\star}$ Summed features are groups of two or three fatty acids that cannot be separated by GLC with the MIDI system. Summed feature 3 comprised $\mathrm{C}_{16: 1} \omega 7 c$ and/or iso- $\mathrm{C}_{15: 0} 2-\mathrm{OH}$.

Science and Technology, where taxonomic studies of the type strain were conducted).

Cells are aerobic, Gram-negative rods $(0.6-0.8 \times 1.5-$ $5.0 \mu \mathrm{m})$ that are motile by means of single polar flagella. Colonies are ivory-coloured, round and convex with clear margins. Grows well on R2A and nutrient agar, but does not grow on trypticase soy agar or MacConkey agar. Catalase- and oxidase-positive. Grows at 5-40 ${ }^{\circ} \mathrm{C}$ (optimally at $28{ }^{\circ} \mathrm{C}$ ) on $\mathrm{R} 2 \mathrm{~A}$, at $\mathrm{pH}$ 6-8 (optimally at $\mathrm{pH} 7$ ) and $0-1 \% \mathrm{NaCl}$. Positive for aesculin hydrolysis, gelatin hydrolysis and $\beta$-galactosidase, but negative for nitrate reduction, indole production, glucose fermentation, arginine dihydrolase and urease (API 20NE test strips). Degrades hypoxanthine, starch and tyrosine, but does not degrade casein, chitin, CM-cellulose, DNA, pectin, Tween
80 or xanthine. Assimilates D-glucose, L-arabinose, Dmannose, $\mathrm{N}$-acetylglucosamine, maltose, potassium gluconate, malic acid, L-rhamnose, itaconic acid, sodium acetate, L-alanine, 3-hydroxybenzoic acid, salicin, 3-hydroxybutyric acid, 4-hydroxybenzoic acid and L-proline, but not Dmannitol, capric acid, adipic acid, trisodium citrate, phenylacetic acid, D-ribose, inositol, sucrose, suberic acid, sodium malonate, lactic acid, potassium 5-ketogluconate, glycogen, L-serine, melibiose, L-fucose, D-sorbitol, propionic acid, valeric acid, L-histidine or potassium 2ketogluconate (API 20NE and API ID 32GN test strips). Positive for alkaline phosphatase, esterase (C4), leucine arylamidase, valine arylamidase, cystine arylamidase, acid phosphatase and naphthol-AS-BI-phosphohydrolase, but negative for esterase lipase (C8), lipase (C14), trypsin, $\alpha-$ chymotrypsin, $\alpha$-galactosidase, $\beta$-glucuronidase, $\alpha$-glucosi-

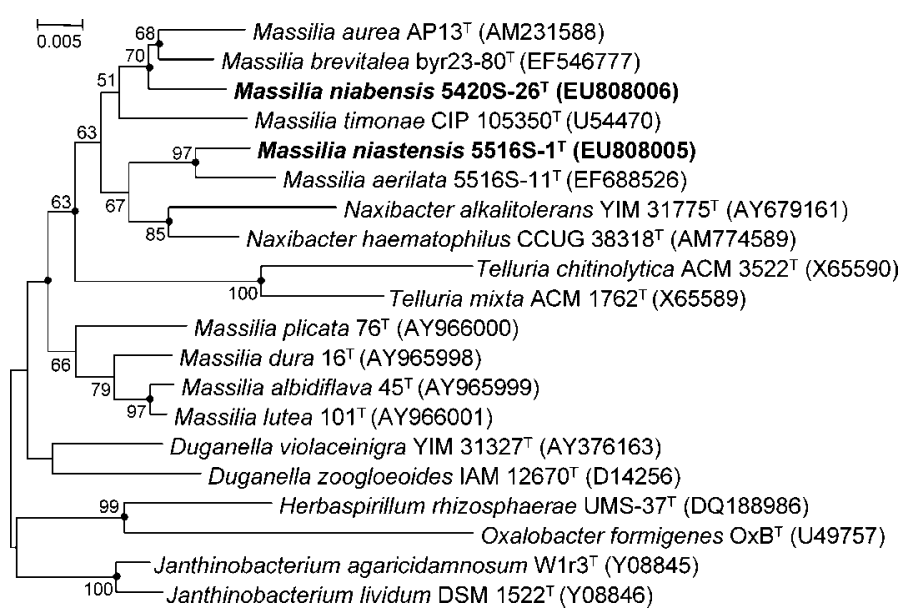

Fig. 1. Neighbour-joining phylogenetic tree, based on 16S rRNA gene sequences, showing the positions of strains $5420 \mathrm{~S}-26^{\top}$ and $5516 \mathrm{~S}-$ $1^{\top}$ with respect to closely related species. Numbers at nodes indicate bootstrap percentages (based on 1000 replications); only values $>50 \%$ are shown. Filled circles indicate that the corresponding branches were also recovered in the maximum-parsimony tree. Bar, 0.005 accumulated changes per nucleotide. 
dase, $\beta$-glucosidase, $N$-acetyl- $\beta$-glucosaminidase, $\alpha$-mannosidase and $\alpha$-fucosidase (API ZYM test strips). The major fatty acids $(>10 \%)$ are summed feature $3\left(\mathrm{C}_{16: 1} \omega 7 \mathrm{c}\right.$ and/or iso- $\left.\mathrm{C}_{15: 0} 2-\mathrm{OH}\right), \mathrm{C}_{16: 0}$ and $\mathrm{C}_{18: 1} \omega 7 c$. The predominant ubiquinone is $\mathrm{Q}-8$. The DNA G $+\mathrm{C}$ content of the type strain is $66.6 \mathrm{~mol} \%$.

The type strain, $5516 \mathrm{~S}-1^{\mathrm{T}}\left(=\right.$ KACC $12599^{\mathrm{T}}=$ DSM $\left.21313^{\mathrm{T}}\right)$, was isolated from an air sample collected from Suwon, Republic of Korea.

\section{Acknowledgements}

This study was supported by the National Academy of Agricultural Science (NAAS), Rural Development Administration, Republic of Korea.

\section{References}

Breznak, J. A. \& Costilow, R. N. (1994). Physicochemical factors in growth. In Methods for General and Molecular Bacteriology, pp. 137154. Edited by P. Gerhardt, R. G. E. Murray, W. A. Wood \& N. R. Krieg. Washington, DC: American Society for Microbiology.

Fitch, W. M. (1971). Toward defining the course of evolution: minimum change for a specific tree topology. Syst Zool 20, 406-416.

Gallego, V., Sánchez-Porro, C., García, M. T. \& Ventosa, A. (2006). Massilia aurea sp. nov., isolated from drinking water. Int J Syst Evol Microbiol 56, 2449-2453.

Groth, I., Schumann, P., Weiss, N., Martin, K. \& Rainey, F. A. (1996). Agrococcus jenensis gen. nov., sp. nov., a new genus of actinomycetes with diaminobutyric acid in the cell wall. Int J Syst Bacteriol 46, 234-239.

Hiraishi, A. (1992). Direct automated sequencing of $16 \mathrm{~S}$ rDNA amplified by polymerase chain reaction from bacterial cultures without DNA purification. Lett Appl Microbiol 15, 210-213.

Kumar, S., Tamura, K. \& Nei, M. (2004). MEGA3: integrated software for molecular evolutionary genetics analysis and sequence alignment. Brief Bioinform 5, 150-163.
La Scola, B., Birtles, R. J., Mallet, M. N. \& Raoult, D. (1998). Massilia timonae gen. nov., sp. nov., isolated from blood of an immunocompromised patient with cerebellar lesions. J Clin Microbiol 36, 28472852.

Lindquist, D., Murrill, D., Burran, W. P., Winans, G., Janda, J. M. \& Probert, W. (2003). Characteristics of Massilia timonae and Massilia timonae-like isolates from human patients, with an emended description of the species. J Clin Microbiol 41, 192-196.

Mesbah, M., Premachandran, U. \& Whitman, W. B. (1989). Precise measurement of the $\mathrm{G}+\mathrm{C}$ content of deoxyribonucleic acid by high-performance liquid chromatography. Int J Syst Bacteriol 39, 159167.

Reasoner, D. J. \& Geldreich, E. E. (1985). A new medium for the enumeration and subculture of bacteria from potable water. Appl Environ Microbiol 49, 1-7.

Saitou, N. \& Nei, M. (1987). The neighbor-joining method: a new method for reconstructing phylogenetic trees. Mol Biol Evol 4, 406-425.

Seldin, L. \& Dubnau, D. (1985). Deoxyribonucleic acid homology among Bacillus polymyxa, Bacillus macerans, Bacillus azotofixans, and other nitrogen-fixing Bacillus strains. Int J Syst Bacteriol 35, 151-154.

Smibert, R. M. \& Krieg, N. R. (1994). Phenotypic characterization. In Methods for General and Molecular Bacteriology, pp. 607-654. Edited by P. Gerhardt, R. G. E. Murray, W. A. Wood \& N. R. Krieg. Washington, DC: American Society for Microbiology.

Weisburg, W. G., Barns, S. M., Pelletier, D. A. \& Lane, D. J. (1991). $16 \mathrm{~S}$ ribosomal DNA amplification for phylogenetic study. J Bacteriol 173, 697-703.

Weon, H. Y., Kim, B. Y., Son, J. A., Jang, H. B., Hong, S. K., Go, S. J. \& Kwon, S. W. (2008). Massilia aerilata sp. nov., isolated from an air sample. Int J Syst Evol Microbiol 58, 1422-1425.

Zhang, Y.-Q., Li, W.-J., Zhang, K.-Y., Tian, X.-P., Jiang, Y., Xu, L.-H., Jiang, C.-L. \& Lai, R. (2006). Massilia dura sp. nov., Massilia albidiflava sp. nov., Massilia plicata sp. nov. and Massilia lutea sp. nov., isolated from soils in China. Int J Syst Evol Microbiol 56, 459463.

Zul, D., Wanner, G. \& Overmann, J. (2008). Massilia brevitalea sp. nov., a novel betaproteobacterium isolated from lysimeter soil. Int $J$ Syst Evol Microbiol 58, 1245-1251. 